\title{
DEVELOPMENT OF TECHNOLOGY FOR REDUCING THE TECHNOGENIC IMPACT OF SUGAR FACTORIES ON THE ENVIRONMENT OF LOCALITIES
}

\author{
Tatyana Polivanova, Natalya Semicheva*, Svetlana Ryabtseva \\ South-West State University, Kursk, Russian Federation
}

This article describes technologies for reducing the technogenic impact of sugar factories on the environment of localities. The monitoring of anthropogenic impact of sugar production on the environment (water, air, soil) to determine environmental assessment of technologies for the production of sugar. The systematization and analysis of monitoring materials was carried out, the ranking of levels of technogenic impact of enterprises based on an integral indicator was performed.

Key words: agribusiness, sugar industry, ecology, ecologization, environmental protection measures

\section{INTRODUCTION}

One of the focal points of the environmental policy of the country is production ecologization, i.e. development and implementation of technologies providing ecological balance in nature, circulation of substances and energy, preventing environment pollution $[1,10,11,12]$.

Sugar industry is one of large agribusiness industries processing plant raw materials. Sugar production is resource-intensive (including all types of resources: water, energy, raw materials); it produces large amount of by-products and wastes such as plant raw material wastes (pulp),intermediate product treatment wastes (filter sediment and flume sludge), and emissions into the atmosphere (saturation and sulphur gases, nitrogen oxide, sugar, pulp and inorganic dust). Annually about 70 $\mathrm{mln}$ tons of secondary resources and wastes are produced [2, 13].

Consequently, sugar mills contaminate the environment with:

- waste water;

- solid wastes of Lime and Gas station;

- CHPP flue gases;

- gas and gas-dust emissions;

- solids;

- waste combustibles and lubricants (diesel oil), oily residues, solvents, paints, petrochemicals;

- hazardous substances (chemical contaminants, heavy metals, pesticides, inorganic dust and vapor, used during sugar beet processing and storage) [3].

Heat, Gas and Water Supply and Ventilation Department of the South West State University has studied sugar industry impact on the environment. 21 sugar mills have been examined (Belgorod region, Kursk region, Voronezh region, Krasnodar krai).

To create a model of a typical sugar mill, the main and auxiliary process flows of the standard sugar production process flow diagram and analysis of pollutant emission into air, water and soil have been studied [4].

The analysis shows that the distinctive feature of sugar production technology is application of gases as auxiliary technological aids, e.g. saturation gas $\left(\mathrm{CO}_{2}\right)$, consumption for one sugar mill is about $7 \mathrm{ml} / \mathrm{m}^{3}$, sulphur gas $\left(\mathrm{SO}_{2}\right)$, consumption is about 50 thousand $\mathrm{m}^{3}$ [5]. Emissions into the atmosphere have been classified according to the sources of pollutants into: process $(75 \%)$, gaseous substances and ventilation (25\%); emissions with various dust content: according to the type of input they are divide into: organized (47\%) and fugitive (up to $3 \%$ ). Concentration of pollutant in vent emissions is not more than: from $4 \mathrm{mg} / \mathrm{m}^{3}$ produced by sugar drying units to $16 \mathrm{mg} / \mathrm{m}^{3}$ produced by lime slacking machines; concentration of contaminants in process emissions is much higher: from $50 \mathrm{mg} / \mathrm{m}^{3}$ produced by CHPP steam boilers to $780 \mathrm{mg} / \mathrm{m}^{3}$ produced by saturation units, but within the limits of Maximum Permissible Emissions.

Chemically, sugar mills emissions are mostly carbon dioxides, sulphur dioxides, nitrogen dioxides and belong to classes 3 and 4. [6].

Water services of sugar mills are at low technological level. At 21 mills under study, only two, at best three of seven water recirculation systems (as per water service layout) are used; they are a system of cooling water of the main building, a CHPP cooling water system and a flume-water system. CHPP cooling towers $(27 \%)$ are used at 8 sugar mills to cool the water of the main building; 11 sugar mills use cooling ponds ( $38 \%), 3$ sugar mills discharge category I water into special ponds. For category II water, outdated compartmented settling tanks are used (55\%); their operation is labor-consuming and water consumption for sludge removal to a filter field is excessive, 4 sugar mills (18\%) use vertical flow tanks and 5 sugar mills (23\%) apply radial flow setting tanks.

For category III water most sugar mills use natural biological treatment in filter fields. (25-30 ha for 1 thousand 
tons of sugar beet) which is a significant ecological problem.

Pollutants produced by sugar mills have been classified into toxic wastes (consumer wastes) and nontoxic wastes (production wastes). In spite of the fact that the amount of solid wastes of the industry is $28 \mathrm{mln}$ tons, the vast majority $(93 \%)$ belong to 4 and 5 classes of hazard [7].

According to the process flow and monitoring data, an average sugar millsprocessing 3,200 tons of sugar beet a day, has been modeled. While processing sugar beet and cane raw sugar, annually more than 1 th. tons of organized gaseous substances are emitted into the ambient air from technological processes and ventilation. They are: carbon dioxide - 479 tons, nitrogen dioxide - 95 tons, sulphur dioxide - 176 tons; dust: sugar - 111 tons, pulp -46 tons and lime -72 tons.; fresh water consumption is 1,650 th. $\mathrm{m}^{3}$, waste water discharge is 1,381 th. $\mathrm{m}^{3}$; and the amount of circulated and subsequently reused water is 14,300 th. $\mathrm{m}^{3}$. Nontoxic contamination in the form of wastes includes: 332 th. tons of sugar beet pulp, 108 th. tons of filter sediment, 60 th. tons of flume-washing sludge, 12.8 th. tons of limestone siftings, 12 th. tons of beet breakage and rootlets. Besides, toxic pollutants as consumption wastes are also generated at the mills: 6.4 tons of waste oils, 0.2 tons of sulphuric acid, 0.6 tons of solvent and paints residues, 1.8 tons of petrochemicals.

To rank levels of technological impact of sugar industry, a new method for calculation points was proposed. The method is based on the integrated index and the weighting coefficient of individual criteria. [8].

Integral index calculation $(\mathrm{Oi})$ is performed by the following formula:

$$
\mathrm{Oi}=0.2 \cdot \mathrm{O}_{\mathrm{c}}+0.3 \cdot \mathrm{K}_{\mathrm{x}}{ }^{\prime}+0.2 \mathrm{~K}_{\mathrm{f}}^{\prime}-0.15 \mathrm{Y}_{\mathrm{b}}-0.15 \mathrm{Y}_{\mathrm{c}}
$$

where: Oc, is the number of recirculation systems;

$\mathrm{K}_{\mathrm{x}}$ is the specific indicator of pulp amount, sent for drying (if pulp drying is not provided, then $K_{x}^{\prime}=1 ; K_{x}^{\prime}=K_{x} \cdot 10^{-1}$ );

$K_{x}$ is the amount of pulp, sent for drying (\% of the total amount);

$K_{f}^{\prime}$ is the specific indicator of filter sludge amount, dry output (if sludge drying is not provided, then $K_{f}^{\prime}=1$; $\left.K_{f}^{\prime}=K_{f} \cdot 10^{-1}\right)$;

$\mathrm{K}_{\mathrm{f}}$ is the amount of filter sludge output in a dry state (\% of the total amount);

$\mathrm{y}_{\mathrm{b}}$ is the specific CHPP emissions ( $\mathrm{kg}$ per 1 ton of beet); $\mathrm{y}_{c}$ is the specific waste water discharge $\left(\mathrm{m}^{3}\right.$ per 1 ton of beet).

Table 1: Weighting coefficient of individual criteria, $B a$

\begin{tabular}{|c|c|c|}
\hline № & Criteria & Weighting coefficient, Ba \\
\hline 1 & Number of recirculation systems at a sugar mill, $\mathrm{O}_{\mathrm{c}}$ & 0.2 \\
\hline 2 & Specific indicator of the amount of pulp sent for drying, $\mathrm{K}_{\mathrm{x}}^{\prime}$ & 0.3 \\
\hline 3 & Specific indicator of filter sludge amount, output in a dry state, $\mathrm{K}_{\mathrm{f}}{ }^{\prime}$ & 0.2 \\
\hline 4 & Specific emissions of $\mathrm{CHPP}, \mathrm{Y}_{\mathrm{b}}(\mathrm{kg}$ per 1 ton of beef $)$ & 0.15 \\
\hline 5 & Specific waste water discharge, $\mathrm{Y}_{\mathrm{c}}\left(\mathrm{m}^{3}\right.$ per 1 ton of processed beet $)$ & 0.15 \\
\hline
\end{tabular}

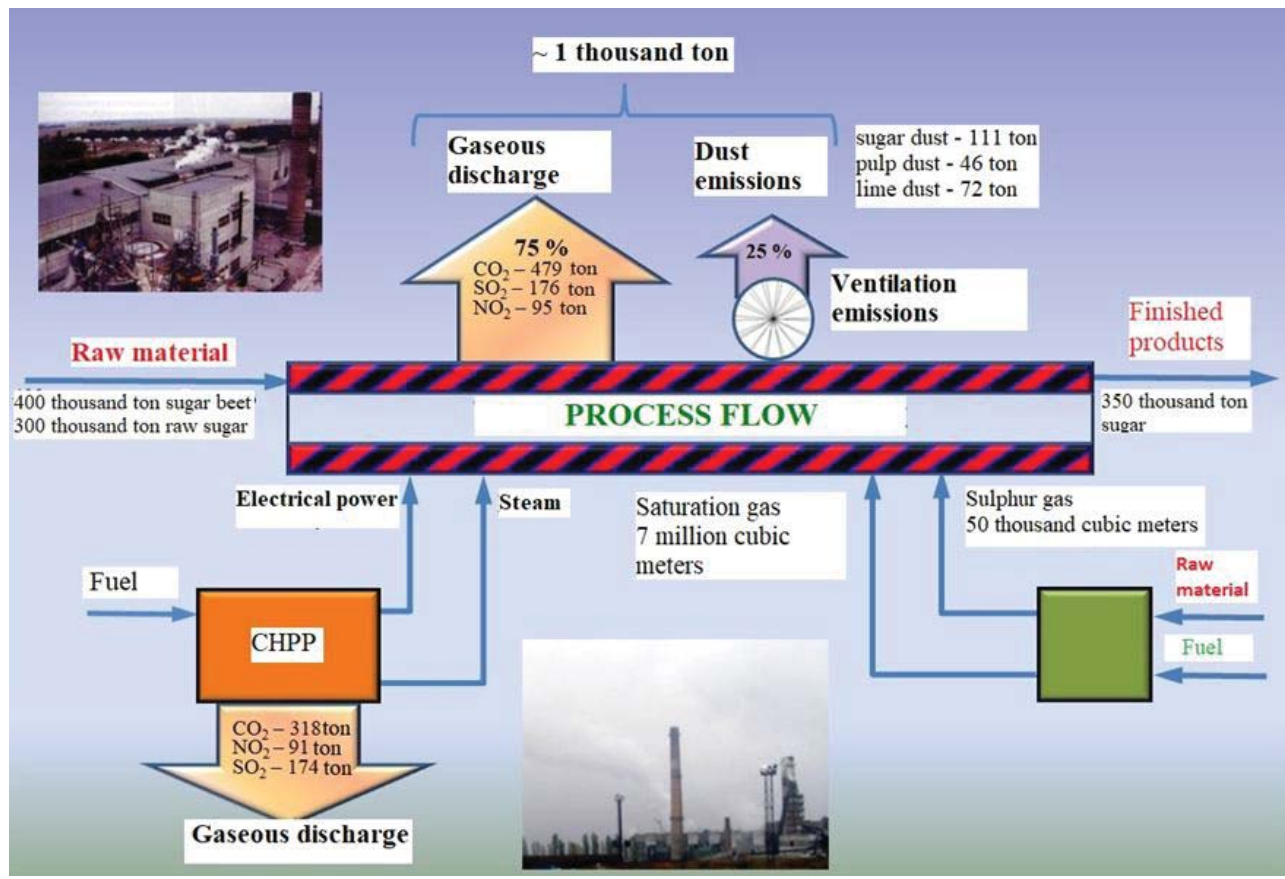

Figure 1: A model of a sugar mill; pollutant emissions into the ambient air 


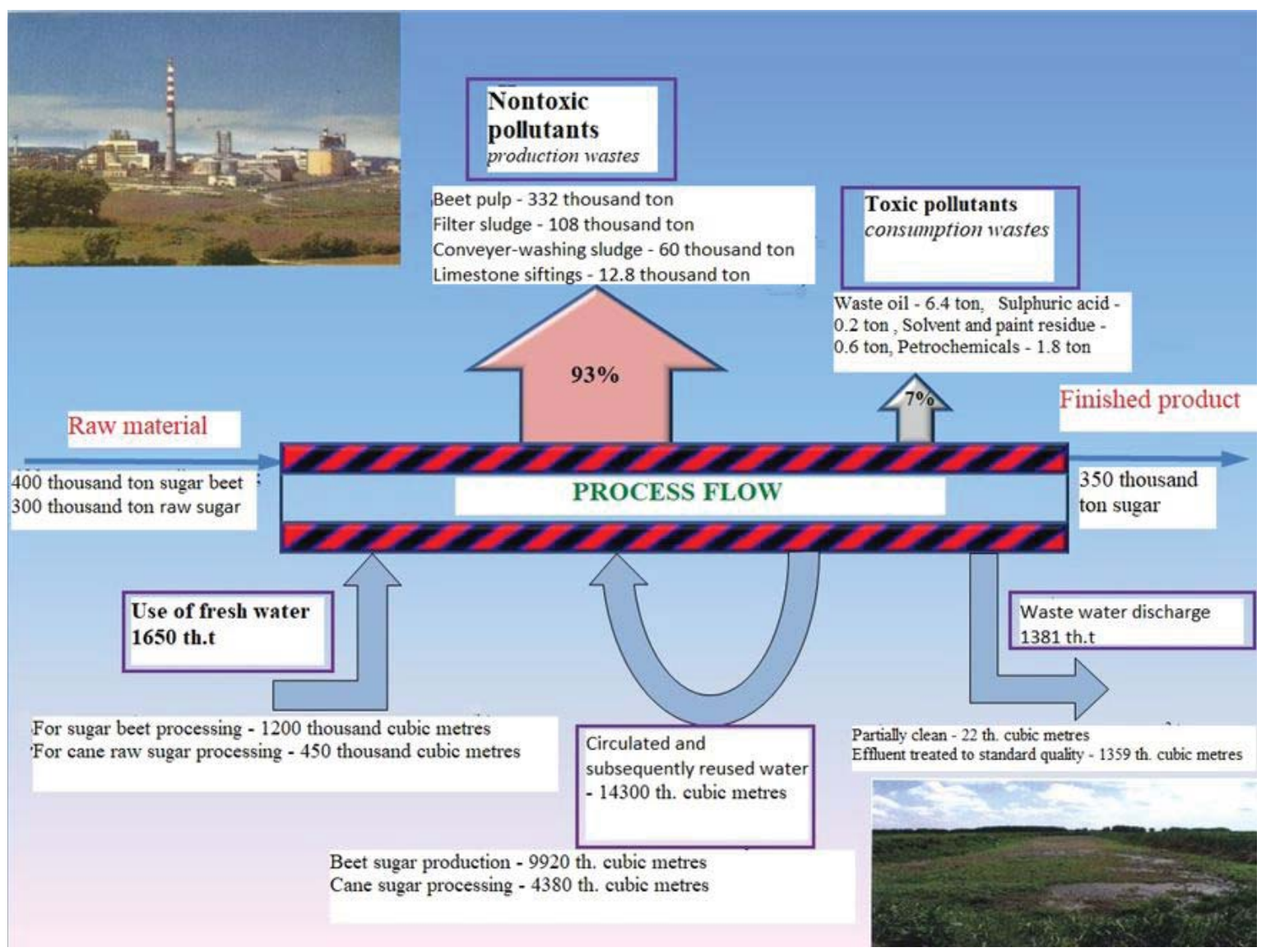

Figure 2: A model of a sugar mill; pollutant emissions into water and soil

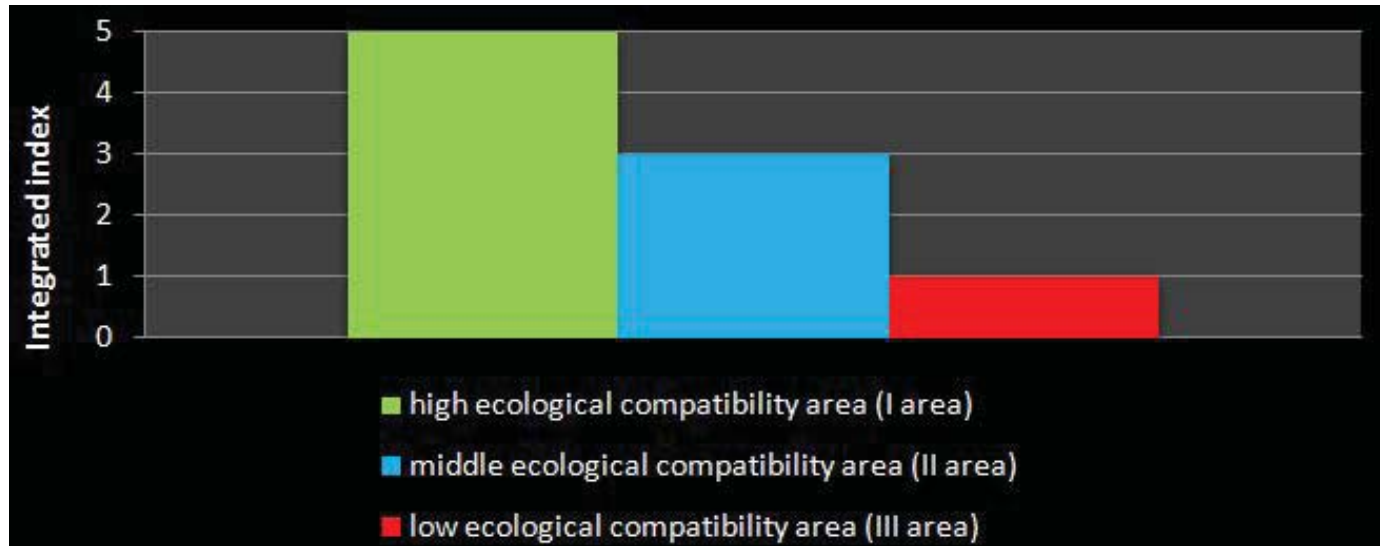

Figure 3: Areas of ecological compatibility of production according to the integrated index

Levels of technological impact have been classified according to the monitoring data taking into account the integrated index. According to the monitoring data, the high grade of ecological compatibility has been given to 8 mills (1 sugar mill in Belgorod region, 1 sugar mill in Voronezh region, 2 sugar mills in Kursk region, and 4 mills in Krasnodar krai).

Based on values of the integrated index of sugar mills three areas of ecological compatibility of production (high, middle and low) have been distinguished (Figure 3).

Studying the diagrams it can be concluded that most environmentally friendly production technologies are applied in Krasnodar krai, mills in Belgorod region are of the middle level of ecological compatibility, mills in Vo- ronezh region are of the low level of ecological compatibility and the lowest level of ecological compatibility is in Kursk region.

Based on the study it can be concluded that sugar industry enterprises significantly affect the environment in the areas nearby, therefore, some environmental protection measures to reduce the impact on the environment shall be taken The main ones among them are:

- introduction of a maximum possible number of recirculation water systems (at least 7 ) with minimum water discharge into waste water systems which enables reduction of fresh water consumption and waste water amount by half; 

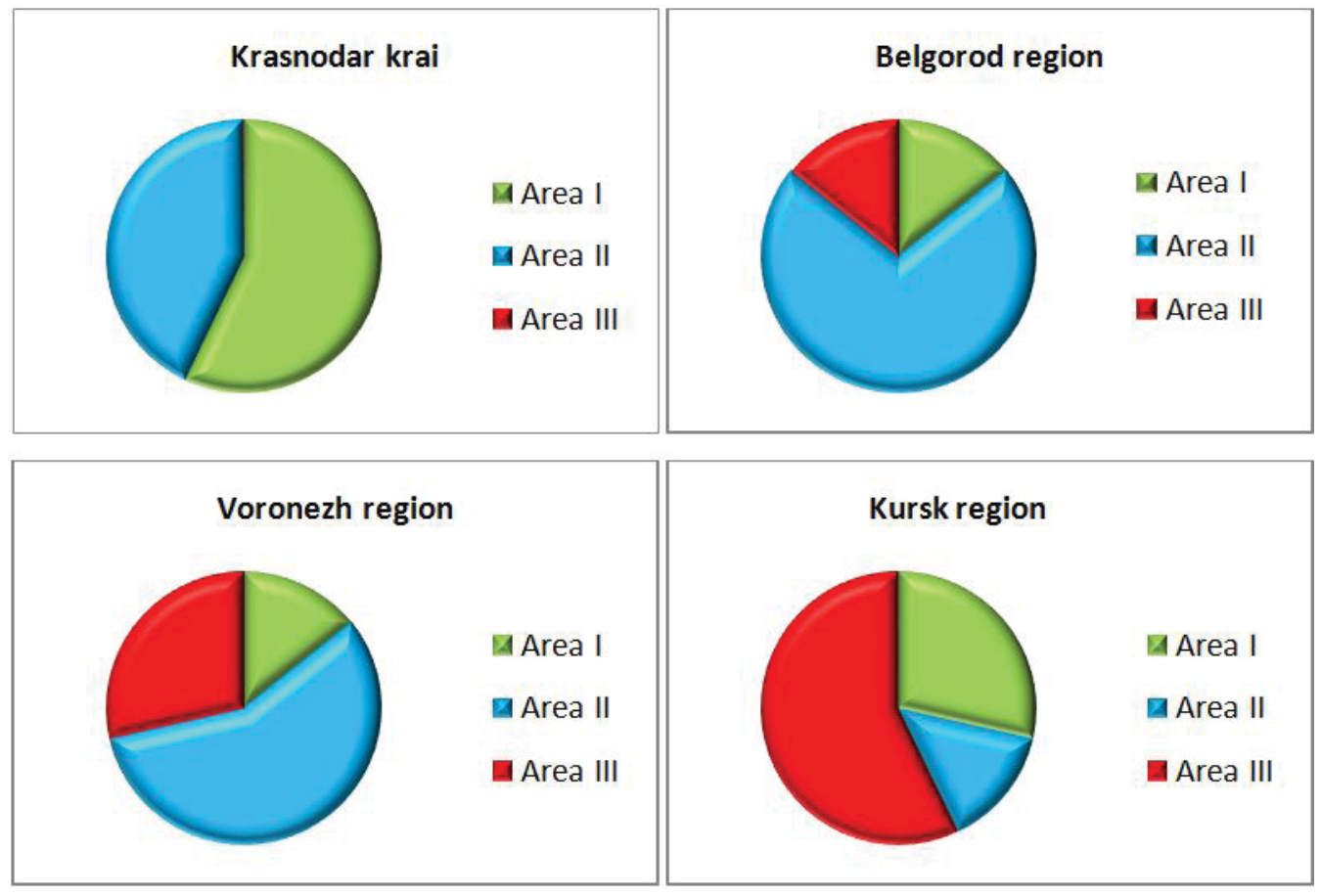

Figure 4: Distribution of sugar mills according to ecological compatibility for each region

- avoidance of hydraulic methods of transporting of filter and flume - washing sludge to filter fields by replacing filter equipment stock in main production lines;

- conversion to intensive dehydration technologies for flume -washing sludge in a settling tank which allows $85 \%$ reduction of waste water discharge in relation to beet weight;

- application of methods of not natural biological treatment which will result in the reduction of areas for waste treatment facilities (filter fields) and release of 50-80 ha of fertile soils;

- implementation of saturation machines of a new design to increase the saturation gas disposal which will provide $30 \%$ reduction of gas consumption in the process line;

- application of membrane technology of defecation which will reduce saturation gas consumption twice;

- application of sugar refinery technology using polyelectrolyte without saturation gas application which annually reduces $\mathrm{CO}_{2}$ consumption by $5 \mathrm{mln} \mathrm{m}^{3}$ for 1 sugar refinery mill [9].

It is also necessary to arrange an ecological control system designed to prevent negative impact on the environment $[7,9,10,11]$.

Therefore, to reduce technological impact of sugar industry on water and air, it is necessary to implement new technologies for core production and for waste water treatment, introduce industrial environmental control and implementation of the environmental management system taking into consideration modern requirements.

\section{REFERENCES}

1. Panczxava E.S., M.M. Shipilov [2007]. Bioenergy in the agro-industrial complex of Russia. Energy Economy Technology Ecology № 8, 32 - 35

2. Burmistrov N. A. [2011]. Formation of a modernizing strategy for the development of food industry enterprises,p. 23.

3. State program of the Kursk region "Reproduction and use of natural resources, environmental protection in the Kursk region", Kursk, 2013.

4. Spichak, V.V. Water management of sugar factories Kursk, 2005,167 p.

5. Morozov V.A., Morozov A.V., Morozova E.N. [2017]. Some Aspects Of Calculation Of Joint Operation Of Sewage Sludge Pumps And Pipeline Networks. Journal of Applied Engineering Science.15(3), 272275.

6. Polivanova T.V., Semicheva N.E., Ryabceva S.A. [2018].Innovative development of recycled water supply for sugar plants. Bulletin of construction equipment. № 7(1007). P.54-56.

7. Polivanova T.V., Semicheva N.E., Polivanova S.A. [2017] Research of environmental problems in the design and construction of sugar industry enterprises. Industrial and civil construction. № 3. p. 79-83.

8. Polivanova T.V., Uvarkin A.V., Frolov K.A., Polivanova S.A. [2014]. The management of precipitation of sugar production conveyor and washing waters is a major environmental problem. Proceedings of Southwestern state University. Series: Equipment and technologies. № 1. p. 125-129. 
9. Polivanova T.V., Frolov K.A., Polivanova S.A., Buromskij V.V. [2014]. Main directions of improving the efficiency of the circulating cooling water supply system in sugar production. Industrial and civil construction. № 2. p. 70-74.

10. Yezhov, V., Ezhova, T., Semicheva, N., \& Makhova, V. [2017]. Outdoor air conditioning. Journal of Applied Engineering Science, 15(3), 313-318.

11. Sergeevich, Y. V., Evgenievna, S. N., Gennadievna, P. E., Vladimirovna, B. N., \& Emmanuel, S. [2019]. To the question of improving energy-saving and environmental characteristics of urban buildings. Journal of Applied Engineering Science, 17(4), 550-554.
12. Bredihin, V. V., Akulshin, A. A., Vladimirovna-Bredihina, N., \& Sergeevna-Pereverzeva, V. [2017]. A method of calculating filtration rate of an infiltration water intake in Kursk region. Journal of Applied Engineering Science, 15(3), 208-211.

13. Bredihin, V. V., Akulshin, A. A., \& Vladimirovna-Bredihina, N. [2017]. Mathematical formulation of the process of suspensions filtration through flat porous partitions. Journal of Applied Engineering Science, 15(4), 422-425. 